\title{
Vitamin D and diabetes mellitus: an update - 2013
}

\author{
Vitamin D e diabetes melito: uma atualização - 2013
}

Luiz Henrique Maciel Griz', Francisco Bandeira', Mônica Andrade

Lima Gabbay², Sergio Atala Dib², Eduardo Freese de Carvalho ${ }^{3}$

\begin{abstract}
Vitamin D deficiency and diabetes mellitus are two common conditions and they are widely prevalent across all ages, races, geographical regions, and socioeconomic conditions. Epidemiologic studies have shown association of vitamin $D$ deficiency and increased risk of chronic diseases, such as cancer, cardiovascular disease, type 2 diabetes, and autoimmune diseases, such as multiple sclerosis and type 1 diabetes mellitus. The identification of $1,25(\mathrm{OH})_{2} \mathrm{D}$ receptors and 1 - $\alpha$-hydroxilase expression in pancreatic beta cells, in cells of the immune system, and in various others tissues, besides the bone system support the role of vitamin $D$ in the pathogenesis of type 2 diabetes. Observational studies have revealed an association between $25(\mathrm{OH})$ D deficiency and the prevalence of type 1 diabetes in children and adolescents. This review will focus on the concept of vitamin D deficiency, its prevalence, and its role in the pathogenesis and risk of diabetes mellitus and cardiovascular diseases. Arq Bras Endocrinol Metab. 2014;58(1):1-8
\end{abstract}

Keywords

Vitamin D; diabetes mellitus; pathogenesis

\section{RESUMO}

A deficiência de vitamina $D$ e o diabetes melito são enfermidades comuns na população e são altamente prevalentes em todas as raças, idades, regiões geográficas e situação socioeconômica. Estudos epidemiológicos mostram uma associação entre hipovitaminose $\mathrm{D}$ com o aumento do risco de doenças crônicas, tais como câncer, doença cardiovascular, diabetes melito do tipo 2 e doenças autoimunes como a esclerose múltipla e o diabetes mellitus do tipo 1. A identificação de receptores da $1,25(\mathrm{OH})_{2} \mathrm{D}$ e da expressão da $1 \alpha$-hidroxilase nas células betapancreáticas, em células do sistema imunológico e em uma variedade de células do organismo além do tecido ósseo, suporta o papel da vitamina $D$ na patogênese do diabetes tipo 2 e do tipo 1. Esta revisão apresenta e discute o conceito de deficiência de vitamina $D$, sua prevalência e seu papel na patogênese e no risco de desenvolvimento do diabetes melito e doenças cardiovasculares. Arq Bras Endocrinol Metab. 2014;58(1):1-8

Descritores

Vitamina D; diabetes melito; patogênese
Endocrinology, Diabetes and Bone Diseases Division of Agamenon Magalhães Hospital of Universidade Federal de Pernambuco (UFPE), Recife, PE, Brazil ${ }^{2}$ Endocrinology Division and Diabetes Center of Universidade Federal de São Paulo, São Paulo, SP, Brazil ${ }^{3}$ Public Health and Epidemiology Division of UFPE, Recife, PE, Brazil

\section{INTRODUCTION}

$\mathrm{V}$ itamin $\mathrm{D}$ deficiency and diabetes mellitus are two common conditions in the elderly population. Vitamin D deficiency is currently a topic of intense interest, and is widely prevalent across all ages, races, geographical regions, and socioeconomic strata. Suboptimal vitamin D status contributes to many conditions, including osteomalacia, osteoporosis, falls, and fractures $(1,2)$. In addition, epidemiologic observations have associated low vitamin D status with an increased risk of non-musculoskeletal diseases, such as cancer (3), multiple sclerosis (4), type 1 diabetes mellitus (5), type 2 diabetes mellitus (6) and cardiovascular disease (7).
Vitamin D (calciferol) is a generic name for a group of fat steroids of which the two major forms are vitamin $\mathrm{D}_{2}$ (ergocalciferol) and vitamin $\mathrm{D}_{3}$ (colecalciferol). Both forms of vitamin D undergo identical metabolism. Vitamin D is obtained from skin irradiation and limited dietary sources. Vitamin D from the skin and diet is metabolized in the liver to $25(\mathrm{OH})$ $\mathrm{D}$, which has a long life and is the major circulating metabolite and marker of vitamin D status (8). In the kidney, 25 -hydroxyvitamin $\mathrm{D}$ is metabolized by the enzyme 25-hydroxyvitamin $\mathrm{D}-\mathrm{l}$ (alpha)-hydroxylase $(\mathrm{CYP} 27 \mathrm{Bl})$ to its active form, $1,25(\mathrm{OH})_{2} \mathrm{D}$, which exerts its effects by means of steroid hormone nuclear 
receptors. The characteristics of $1,25(\mathrm{OH})_{2} \mathrm{D}$ are those of a hormone, and consequently vitamin $\mathrm{D}$ is a prohormone, rather than a true vitamin.

Vitamin D is not only essential for maintaining bone health, but it also plays a role in several other biochemical mechanisms within the human body. The mechanism of action of the active form of vitamin $\mathrm{D}$ is similar to that of other steroid hormones and is mediated by its binding to vitamin D receptor (VDR). VDRs are found in most tissues, not just in those that participate in the classic actions of vitamin D such as bones, intestines and kidneys, and the enzyme responsible for converting $25(\mathrm{OH}) \mathrm{D}$ to $1,25(\mathrm{OH})_{2} \mathrm{D}$ is also expressed in a variety of extrarrenal sites, such as endothelial cells, beta cells, and immune cells $(9)$.

The number of subjects with type 2 diabetes mellitus is rising, due to effect of age, growth of the population, sedentariness and, mainly, obesity. Although changes in lifestyle, particularly weight loss and physical activity, delay the progression of diabetes, weight loss is difficult to be achieved and maintaind. The identification of easily modifiable risk factors is therefore urgently needed for primary prevention of diabetes. Certain nutritional factors, such as vitamin $\mathrm{D}$ are also believed to play a role, and it has been suggested that endemic low vitamin D status contributes to the increased prevalence of diabetes mellitus. There is increasing evidence that vitamin $\mathrm{D}$ metabolism affects the risk of diabetes. Studies in humans have shown that vitamin D supplementation in infancy reduces the risk of type 1 diabetes mellitus during early adulthood (10). Published studies in animals identified a pancreatic receptor to the active metabolite of vitamin $\mathrm{D}$. As vitamin $\mathrm{D}$ modulates insulin receptor gene expression and insulin secretion, it is an interesting environmental candidate for type 2 diabetes mellitus (11).

This review will focus on the concept of vitamin $\mathrm{D}$, its prevalence, and its role in the pathogenesis of diabetes mellitus, its risks and complications.

\section{CONCEPT AND PREVALENCE OF VITAMIN D INSUFFICIENCY AND DEFICIENCY}

The concept of normal $25(\mathrm{OH}) \mathrm{D}$ concentration is a challenge. It has been suggested that vitamin $\mathrm{D}$ deficiency be defined as a $25(\mathrm{OH}) \mathrm{D}$ below $20 \mathrm{ng} /$ $\mathrm{mL}$, insufficiency as a $25(\mathrm{OH}) \mathrm{D}$ of $21-29 \mathrm{ng} / \mathrm{mL}$, and sufficiency as a $25(\mathrm{OH}) \mathrm{D}$ of $30-100 \mathrm{ng} / \mathrm{mL}$ (to convert to nanomoles per liter, multiply by 2.496 ) (12).
A meta-analysis of high-quality primary prevention randomized control trials (RCT) of vitamin D and fracture risk consistently found that antifracture efficacy started at $25(\mathrm{OH}) \mathrm{D}$ levels of at least $30 \mathrm{ng} / \mathrm{mL}$ (13).

The guideline, written by the Endocrine Society Task Force, reports that $25(\mathrm{OH}) \mathrm{D}$ levels of $30 \mathrm{ng} /$ $\mathrm{mL}$ or higher compared with $20 \mathrm{ng} / \mathrm{mL}$ provide increase benefits (14). In contrast, the Institute of Medicine (IOM) report, based on evidence from observational studies and recent randomized trials, suggests that a serum level of $20 \mathrm{ng} / \mathrm{mL}$ of $25(\mathrm{OH})$ $\mathrm{D}$ would protect $97.5 \%$ of the population against adverse skeletal outcomes (15). Hypovitaminosis D has become endemic owing to the insufficient ingestion of vitamin $\mathrm{D}$ in combination with the use of sun protection clothing and sunblocks. The prevalence of vitamin $\mathrm{D}$ deficiency has been reported with great frequency even in sunny regions of the world. Studies on the prevalence of hypovitaminosis D in Saudi Arabia, Australia, Turkey, the Arab Emirates and India have shown that $30 \%-50 \%$ of children and adults had 25(OH)D levels below $20 \mathrm{ng} / \mathrm{mL}$. In Recife (latitude $\left.10^{\circ} \mathrm{S}\right)$, Pernambuco,Brazil, the prevalence of vitamin D deficiency in postmenopausal women was $8 \%$ for $25(\mathrm{OH}) \mathrm{D}$ values below $15 \mathrm{ng} / \mathrm{mL}$ and $43 \%$ for those below $25 \mathrm{ng} / \mathrm{mL}$ (16).

An observational study carried out in Italy in postmenopausal women revealed that vitamin D levels in postmenopausal women were lower in those with type 2 diabetes mellitus than in those in the control group (39\% vs. 25\%) (17). A Japanese study evaluating 581 diabetic patients and 51 nondiabetic ones showed a prevalence of hypovitaminosis $\mathrm{D}(<20 \mathrm{ng} / \mathrm{mL})$ of $75 \%$ with no differences between the type 2 diabetic patients and the control group (18). A study carried out in United Kingdom evaluated the prevalence of hypovitaminosis $\mathrm{D}$ in type 2 diabetic patients in an Asian community and its impact on the control of glycemia (19). The results revealed that the prevalence of vitamin $\mathrm{D}(<20 \mathrm{ng} / \mathrm{mL})$ was $>80 \%$, being more common in the diabetics than in the control group ( $83 \%$ vs. $70 \%$; $\mathrm{p}=0.07$ ), and that the glycated hemoglobin levels were higher in the women with vitamin $\mathrm{D}$ deficiency.

\section{Vitamin $\mathbf{D}$ and insulin resistance}

The identification of $1,25(\mathrm{OH})_{2} \mathrm{D}$ receptors and the $1 \alpha$ hydroxilase expression in pancreatic beta cells support the possibility of vitamin D role in the 
pathogenesis of type 2 diabetes mellitus (20). In animals it has been demonstrated that the secretion of pancreatic insulin is inhibited by vitamin $\mathrm{D}$ deficiency (21) and that in humans vitamin D deficiency is related to glucose intolerance and type 2 diabetes mellitus (22). Hypovitaminosis D leads to a deficiency in the secretion of insulin and induces glucose intolerance (23), while its replacement with vitamin D reestablishes these abnormalities (24).

Vitamin D affects the function of beta cells in various ways. The active form of vitamin $\mathrm{D}$ exerts its effects by activating the nuclear vitamin $\mathrm{D}$ receptor (VDR). The binding of $1,25(\mathrm{OH})_{2} \mathrm{D}$ to the VDR leads to the transcription of genes regulated by $1,25(\mathrm{OH})_{2} \mathrm{D}$. The effect of vitamin $\mathrm{D}$ on insulin synthesis and secretion is evidenced by the presence of the vitamin $\mathrm{D}$ response element (VDRE) in the human insulin gene promoter and transcriptional activation of the human insulin gene caused by $1,25(\mathrm{OH})_{2} \mathrm{D}(25)$. An indirect effect of vitamin $\mathrm{D}$ on beta cells may be mediated by its regulation in the extracellular concentration of calcium and the influx of calcium through the beta cells (26).

Vitamin D may also affect insulin resistance through the renin-angiotensin-aldosterone system. It is believed that angiotensin II contributes to increased insulin resistance by inhibiting the action of insulin in the vascular tissue and skeletal muscle, leading to a decrease in glucose uptake (27). Data support the vitamin $\mathrm{D}-\mathrm{VDR}$ complex as a potential regulator of renin activity in humans and polymorphisms in the VDR gene may be associated with the pathogenesis of type 2 diabetes mellitus by influencing insulin resistance (28).

However, whether vitamin D may influence insulin secretion and action is controversy. Although some studies found no association between serum $25(\mathrm{OH})$ D levels and parameters of insulin action (29), others have shown positive associations. In the Canadian Prospective Metabolism and Islet cell Evaluation (PROMISE) study cohort (30), three univariate analyses indicated a significant positive association between serum $25(\mathrm{OH}) \mathrm{D}$ and the insulin sensitivity index for the oral glucose tolerance test (IS-OGTT): $r$ $=0.30, \mathrm{p}<0.001$. A significant negative association was found between serum $25(\mathrm{OH}) \mathrm{D}$ and the homeostasis model assessment (HOMA-IR): $\mathrm{r}=-0.29, \mathrm{p}<0.001$, as well as significant positive associations between serum $25(\mathrm{OH}) \mathrm{D}$ levels and the insulinogenic index/ HOMA ratio: $\mathrm{r}=0.14, \mathrm{p}=0.002$. In the multivariate regression analyses, serum $25(\mathrm{OH}) \mathrm{D}$ was a significant independent predictor of insulin sensitivity and beta cell function across all models (31).

In HIV positive patients there is prolonged exposure to the HIV virus and anti-retroviral therapy (ART), and both have been associated with metabolic abnormalities and insulin resistance. Vitamin D deficiency has been reported to be higher in various age groups of HIVinfected individuals, ranging from $60 \%$ of adolescents and young adults with serum $25(\mathrm{OH}) \mathrm{D}$ levels of less than $10 \mathrm{ng} / \mathrm{mL}$ in the Netherlands $(32)\left(40^{\circ} \mathrm{N}\right)$ to more than $80 \%$ of adults, with a mean age of 41 years, showing serum $25(\mathrm{OH}) \mathrm{D}$ levels of less than $18 \mathrm{ng} /$ $\mathrm{mL}$ in Italy $\left(30^{\circ} \mathrm{N}\right)$. In a group of premenopausal HIV women with a mean age of 40 years living in the city of Recife ( $10^{\circ} \mathrm{S}$ ), $60 \%$ of them with lipodystrophy, $80 \%$ with dyslipidemia and $38 \%$ with metabolic syndrome, we found a $41 \%$ prevalence of vitamin $\mathrm{D}$ deficiency using a cut point of $30 \mathrm{ng} / \mathrm{mL}$ for serum 25(OH)D. After full adjustments, total serum cholesterol levels and the duration of ART were independently associated with vitamin $\mathrm{D}$ deficiency (33).

\section{Vitamin D and type 2 diabetes mellitus}

Vitamin D deficiency appears to predispose individuals to becoming type 2 diabetics, and there is evidence from observational studies that suggests an association between low levels of vitamin $\mathrm{D}$ and a risk of type 2 diabetes mellitus.

A decrease in the concentration of vitamin D was reported in a population of Asians from Bangladesh resident in London at risk for type 2 diabetes mellitus compared with individuals with no such risk and who also presented a higher prevalence of type 2 diabetes mellitus than a British Caucasian population (34).

An English cohort (6) comprising a total of 524 randomly selected nondiabetic men and women, aged 40-69 years at baseline, with measurements for serum $25(\mathrm{OH}) \mathrm{D}$ and IGF- 1 in the population-based Ely Study, had their glycemic status (oral glucose tolerance), lipids, insulin, anthropometry, and blood pressure measured and metabolic syndrome risk (metabolic syndrome $\mathrm{z}$ score) derived at baseline and at 10 years of followup. This prospective study reports inverse associations between baseline serum $25(\mathrm{OH}) \mathrm{D}$ and future glycemia and insulin resistance. These associations are independent of risk factors and potential confounders. These findings confirm results from a Finnish cohort study showing a significant inverse association between 
serum $25(\mathrm{OH}) \mathrm{D}$ and risk of type 2 diabetes in a simple model. However, the association was attenuated in the multivariate analysis, adjusting for potential risk factors for type 2 diabetes.

An analysis from the Nurse Health Study demonstrated that women with a mean ingestion of vitamin D greater than 800 IU per day had a 33\% lower risk of type 2 diabetes mellitus than those whose daily ingestion was less than $200 \mathrm{IU}$ (35).

To determine the association between serum $25(\mathrm{OH})$ $\mathrm{D}$ and diabetes risk and whether it varies according to ethnicity, an analysis of data from the Third national and Nutrition Examination Survey (1988-1994) was carried out. In this cross-sectional survey of a nationally representative sample of the U.S population, $25(\mathrm{OH}) \mathrm{D}$ was available from 6,228 people $(2,766$ non-Hispanic whites, 1,736 non-Hispanic blacks, and 1,726 Mexican Americans), aged $\geq 20$ years with fasting and/or 2-h plasma glucose and serum insulin measurements. The results showed an inverse association between vitamin D status and diabetes, possibly involving resistance, in non-Hispanic whites and Mexican Americans, but not in non-Hispanic blacks (36).

All this data suggests that hypovitaminosis D may be a major risk factor in glucose intolerance in some individuals, but not in all populations. One explanation for the lack of association could be the existence of a variable effect in the threshold between different ethnic groups. It is possible that a particular population may have a diminished sensibility to vitamin $\mathrm{D}$ or to the effects of the parathyroid hormone (PTH). A cross-sectional study performed on obese female adolescent Afro-Americans suggested that $25(\mathrm{OH}) \mathrm{D}$ concentrations $<15 \mathrm{ng} / \mathrm{mL}$ represent the threshold from which vitamin $\mathrm{D}$ deficiency produces a negative effect on insulin sensibility (37), and adolescents in NHANES III with serum $25(\mathrm{OH}) \mathrm{D}$ levels of less than $15 \mathrm{ng} / \mathrm{mL}$ were more likely to have elevated blood glucose levels than those with the highest $25(\mathrm{OH}) \mathrm{D}$ values (> $26 \mathrm{ng} / \mathrm{mL})(\mathrm{OR}, 2.5$; 95\% CI, 1.0-6.4) (38).

Unlike observational studies, experimental studies lack evidence to support the hypothesis that vitamin D supplementation reduces the risk of diabetes or glucose intolerance. In a meta-analysis (39) published in 2007 , none of the six studies reviewed was able to demonstrate a significant change in glucose intolerance. However, three of the studies were of short duration ( $\leq 3$ months), and two of these employed the active form of vitamin $\mathrm{D}$ (1,25-dihydroxyvitamin $\mathrm{D}_{3}$ ). In addition, the primary outcome of these studies was not the effect of vitamin D supplementation on glucose metabolism. In the placebo-controlled Women's Health Initiative (WHI), the use of calcium supplement of $1,000 \mathrm{mg}$ per day and vitamin $\mathrm{D}_{3} 400 \mathrm{IU}$ per day failed to reduce the risk of progression to diabetes over a period of seven years (40). The null result may, however, be attributable to the use of a low dose of vitamin $\mathrm{D}$ in the active treatment group.

In a systematic review (4l) of studies published in English using Medline up to the end of February 2011, a total of eight observational studies and 11 interventional studies were included, in order to ascertain the association between vitamin D status and the incidence of type 2 diabetes mellitus and the effect of vitamin D supplementation on blood glucose results. The daily ingestion of $>500 \mathrm{IU}$ of $25(\mathrm{OH}) \mathrm{D}$ reduced the risk of diabetes by $13 \%$ a against an ingestion of $<200$ IU per day. Individuals with higher $25(\mathrm{OH}) \mathrm{D}$ levels (> $25 \mathrm{ng} / \mathrm{mL}$ ) had a lower risk of developing type 2 diabetes than those in the group with $25(\mathrm{OH})$ D levels of $<14 \mathrm{ng} / \mathrm{mL}$. In a post-hoc analysis of eight studies comprising individuals with normal glucose tolerance levels at baseline, and in three small studies (32-60) of patients with type 2 diabetes vitamin D supplementation had no effect on the blood glucose results.

To determine whether vitamin $\mathrm{D}$ supplementation, with or without calcium, improved glucose homeostasis in adults at risk for diabetes, a randomized, doubleblind, placebo-controlled study (42) was conducted, assigned in a 2-by-2 factorial-design, in which patients were given either cholecalciferol (2000 IU once daily), or calcium carbonate (400 $\mathrm{mg}$ twice daily) for 16 weeks. The results showed that supplementation with cholecalciferol, but not with calcium, improved beta cell function and had only a marginal effect on attenuating the rise in glycated hemoglobin. However, supplementation with cholecalciferol does not improve glycemic control in diabetic subjects with normal serum $25(\mathrm{OH}) \mathrm{D}$ levels.

\section{Vitamin D and cardiovascular disease}

A growing body of evidence suggests that low levels of $25(\mathrm{OH}) \mathrm{D}$ may adversely affect the cardiovascular system (43).

Cross-sectional studies show associations between decreased sun exposure or hypovitaminosis D and 
increased risk for myocardial infarction, stroke, heart failure, and peripheral arterial disease, and studies in rodents have shown that vitamin $\mathrm{D}$ protects against cardiac hypertrophy and myocardial dysfunction (44).

Several mechanisms may explain the link between vitamin $\mathrm{D}$ deficiency and cardiovascular disease. Vascular smooth muscle cells and endothelial cells express receptors for vitamin $\mathrm{D}$ and have the ability to convert circulating $25(\mathrm{OH}) \mathrm{D}$ into $1,25(\mathrm{OH})_{2} \mathrm{D}(45)$. In vitro, activated $1,25(\mathrm{OH})_{2} \mathrm{D}$ suppresses renin gene expression, and regulates the growth and proliferation of vascular smooth muscle cells and cardiomycytes $(44,46)$.

Demographic data in a sample representative of the United States from the Third National Health and Nutrition Examination Survey revealed that $25(\mathrm{OH})$ D levels are associated with important cardiovascular disease risk factors. The prevalence of diabetes mellitus (odds ratio 1.98), obesity (odds ratio 2.29), increased levels of triglycerides (odds ratio 1.47) and arterial hypertension (odds ratio 1.30) were all significantly greater in the lower quartiles of the $25(\mathrm{OH}) \mathrm{D}$ serum levels than in the higher quartiles $(<0.001$ for all $)$ (47). Pilz and cols. found an association of vitamin $\mathrm{D}$ deficiency with heart failure and sudden cardiac death (SCD) in a large cross-sectional study of patients referred for coronary angiography. After adjustment for cardiovascular risk factors, the hazard ratios (with 95\% confidence intervals) for death due to heart failure and for SCD were 2.84 (1.20-6.74) and 5.05 (2.13-11.97), respectively, when comparing patients with severe vitamin $\mathrm{D}$ deficiency $[25(\mathrm{OH}) \mathrm{D}<10 \mathrm{ng} / \mathrm{mL}]$ with persons in the optimal range $[25(\mathrm{OH}) \mathrm{D}>30 \mathrm{ng} / \mathrm{mL}]$ (48). On the other hand, a systematic review and metaanalysis found (51 eligible trials of moderate quality) that $25(\mathrm{OH}) \mathrm{D}$ was associated with nonsignificant effects on the patient-important outcomes of death [RR, 0.96; 95\% confidence interval (CI), 0.93, 1.00; $P=0.08]$, myocardial infarction (RR, $1.02 ; 95 \% \mathrm{CI}$, $0.93,1.13 ; P=0.64)$, and stroke $(\mathrm{RR}, 1.05 ; 95 \% \mathrm{CI}$, $0.88,1.25 ; P=0.59)(49)$.

A study verified the relationship between hypovitaminosis D and intimal medial thickening (IMT) of the common carotid artery, measured by ultrasonography among 390 type 2 diabetic patients. Hypovitaminosis $\mathrm{D}$ was defined as a serum $25(\mathrm{OH}) \mathrm{D}$ concentration $\leq$ $15 \mathrm{ng} / \mathrm{mL}$ and IMT as a focal thickening $>1.2 \mathrm{~mm}$ at the level of the common carotid artery. They found a strong inverse and independent the association between serum $25(\mathrm{OH}) \mathrm{D}$ and carotid artery IMT. The patients with hypovitaminosis $\mathrm{D}(\mathrm{n}=130)$ had a marked increase in common carotid artery IMT $(1.10 \pm 0.15 \mathrm{vs}$. $0.87 \pm 0.14 \mathrm{~mm}, \mathrm{p}<0.001)(50)$.

Despite a large number of cross-sectional studies and a limited number of clinical trials that evaluated $25(\mathrm{OH}) \mathrm{D}$ concentrations as a potential determinant of cardiovascular disease and type 2 diabetes, it remains uncertain whether improving vitamin $\mathrm{D}$ status would reduce risk of these conditions.

\section{Vitamin D and type 1 diabetes mellitus}

Type $\mathrm{l}$ diabetes mellitus (TID) is caused by a complex autoimmune process associated with altered humoral and cellular immunity. The autoimmune response involves both $\beta$-cell specific autoantibodies and autoreactive pathogenic CD4 and CD8T cells infiltrating the pancreatic islets (insulitis). The prediabetic phase of TID may have relapsing-remitting course that leads to slowly progressive pancreatic islet $\beta$-cell failure. Progression occurs depending on the interplay between antigen spreading, $\beta$-cell proliferation and loss of regulatory $\mathrm{T}$ (Treg) cells.

In the last few years, intervention trials in newonset TID has been taken to silence and/or modulate this altered immune response. A growing body of evidence from animal and in vitro studies suggests the potential of $25(\mathrm{OH}) \mathrm{D}$ to modulate the immune response: 1) the presence of VDR on human activated inflammatory cells, 2) the ability of $25(\mathrm{OH}) \mathrm{D}$ to inhibit lymphocyte proliferation and 3 ) the ability of activated macrophages to produce $1,25(\mathrm{OH})_{2} \mathrm{D}$, expressing CYP27B1. Additionally, most tissues in the body have VDR, which are also expressed in activated $\mathrm{T}$ and $\mathrm{B}$ human lymphocytes.

Initial studies showed that $25(\mathrm{OH}) \mathrm{D}$ not only acts suppressing lymphocyte proliferation, but may also modify the Thl/Th2 cytokine profile, which might help to limit the potential tissue damage associated with Thl cellular immune responses (5l). However a subsequent analysis demonstrated that although in vitro $25(\mathrm{OH}) \mathrm{D}$ seems to support a shift from Thl to $\mathrm{Th} 2$, its effects in vivo on $\mathrm{T}$ cells are more complex, showing both inhibition of Thl and Th2 cytokines, and reduced levels of Thl cells.

In animal models (mostly NOD mouse) high doses of $1,25(\mathrm{OH})_{2} \mathrm{D}$ successfully reduce the incidence of diabetes by decreasing the numbers of effector $\mathrm{T}$ 
cells, inducting Treg cells and reducing chemokine production by islet cells (52). Treg cells exert suppressor rather than effector functions, and it seems that the differentiation of Treg is an important mechanism linking $1,25(\mathrm{OH})_{2} \mathrm{D}$ and adaptive immunity. The immunosuppressive mechanism is probably mediated by the induction of tolerogenic antigen presenting cells (like dendritic cells), increased IL-10 secretion and the expression of Toll-like receptor 9 (TLR9) by Tregs, suggesting a novel link between innate and adaptive immune response.

It also has been reported that exposition of human $\beta$ cell to $1,25(\mathrm{OH})_{2} \mathrm{D}$ protects them from death by reducing expression of MHC class I molecules, inducing expression of anti-apoptotic A20 protein and decreasing expression of FAS (that regulates activationinduced cell death) (53).

In vivo studies have shown that $1,25(\mathrm{OH})_{2} \mathrm{D}$ inhibits the expression of inflammatory cytokines in monocytes, such as IL-6, TNF-alfa, IL-8, and IL-12 in normal individuals. The influence of this vitamin on cytokine production by lymphocytes may be another important link between the $25(\mathrm{OH}) \mathrm{D}$ and the immune system (54). Other facets of T-cell function may also be affected by the hormone, such as the homing of $\mathrm{T}$ cells to specific tissues. The studies suggested that $1,25(\mathrm{OH})_{2} \mathrm{D}$ acts inhibiting migration of $\mathrm{T}$ cells to lymph nodes.

There are data showing that $25(\mathrm{OH}) \mathrm{D}$ supplementation to offspring during infancy, as well as dietary exposure during pregnancy, was associated with a reduced risk of human type 1 diabetes. Children who took 2000UI regularly had a RR of 0.22 (0.05-0.89), while children suspected of having rickets during the first year of life had a RR of 3.0 (1.0-9.0) risk of T1D (10). It is interesting to observe that in Finland, while the recommended dosage of $25(\mathrm{OH}) \mathrm{D}$ has decreased gradually in the last few decades, associated with a decrease in compliance to supplementation recommendations, there was an increase in the incidence of TlD. Together with the observation that incidence rates of TID tended to be higher at higher latitudes in both hemispheres, the association of ultraviolet B irradiance with risk of TID was observed in 51 regions worldwide, which raises the possibility of $25(\mathrm{OH}) \mathrm{D}$ having a role in the development of the disease. In addition, a number of observational studies have revealed an association between $25(\mathrm{OH}) \mathrm{D}$ deficiency, and the prev- alence of TID in children and adolescents compared with non-diabetic individuals (55).

Another piece of evidence of the complex role of $25(\mathrm{OH}) \mathrm{D}$ is the extensive genetic analyses linking the polymorphic variation in the genes for several components of the $25(\mathrm{OH}) \mathrm{D}$ metabolic and signaling system to TID. Some specific VDR gene haplotypes appear to protect against diabetes, while polymorphisms in the CYP27Bl gene have been shown to affect diabetes susceptibility $(56,57)$. Given the evidence that variation in the CYP27Bl etiologically contributes to TID risk, other genes that control vitamin $\mathrm{D}$ metabolism are also biologically plausible candidates, and should be studied.

In a clinical setting, two recent trials found no significant effect of $1,25(\mathrm{OH})_{2} \mathrm{D}$ on the preservation of $\beta$-cell function after type 1 diabetes onset $(58,59)$. Nevertheless, the dose and mechanistic action of vitamin $\mathrm{D}$ are still under discussion. On the other hand, in a randomized, double-blind, placebo-controlled trial in new-onset T1D, we studied the effect of 2000 IU of $25(\mathrm{OH}) \mathrm{D}$ on peripheral cytokine levels, Treg cells and the decline of residual $\beta$-cell function. We found that the cumulative incidence of progression to undetectable $(\leq 0.1 \mathrm{ng} / \mathrm{ml})$ fasting serum C-peptide during the 18 months of follow-up reached $18.7 \%$ in the $25(\mathrm{OH}) \mathrm{D}$ group, and $62.5 \%$ in the placebo group $(\mathrm{P}=.012)$ while stimulated $\mathrm{C}$-Peptide reached this level in $6.2 \%$ of the $25(\mathrm{OH}) \mathrm{D}$ and $37.5 \%$ of placebo group $(\mathrm{P}=.047)$. We also found a tendency to increase IL-10 and Treg cells $\left(\mathrm{CD} 4{ }^{+} \mathrm{CD} 25^{+} \mathrm{Foxp}^{3}\right)$, which might have contributed to the less progressive $\beta$-cell decay in the $25(\mathrm{OH}) \mathrm{D}$ group $(60)$.

In any case, further studies based on large patient cohorts are needed to show whether the administration of $25(\mathrm{OH}) \mathrm{D}$ or $1,25(\mathrm{OH})_{2} \mathrm{D}$ significantly reduces the risk of TID or contribute to the preservation of C-peptide after the diagnosis.

\section{CONCLUSIONS}

There is evidence that vitamin D deficiency leads to glucose intolerance and predisposes to type 2 diabetes mellitus, while the restoration of vitamin $\mathrm{D}$ levels may reduce the risk of type 1 diabetes mellitus. Despite observational studies showing a strong association between vitamin $\mathrm{D}$ deficiency and diabetes mellitus, randomized clinical trials with vitamin D supplementation are of short duration, with small numbers of patients, and small doses of vitamin D 
supplementation, thereby not permitting any definitive conclusions. Questions persist about the optimal level of $25(\mathrm{OH}) \mathrm{D}$ to prevent the risk of developing diabetes mellitus. However, a large long-term clinical trials are needed to clarify these issues. Vitamin D is inexpensive and should a trial confirm its benefit in the prevention of diabetes, it will have a major impact on public health.

Disclosure: no potential conflict of interest relevant to this article was reported.

\section{REFERENCES}

1. Holick MF. Vitamin D: importance in the prevention of cancers, type 1 diabetes, heart disease, and osteoporosis. Am J Clin Nutr. 2004;79(3):362-71.

2. Bischoff-Ferrari HA, Dawson-Hughes B, Willett WC, Staehelin HB, Bazemore MG, Zee Ry, et al. Effect of vitamin D on falls: a metaanalysis. JAMA. 2004;291(16):1999-2006.

3. Garland CF, Garland FC, Gorham ED, Lipkin M, Newmark H, Mohr $\mathrm{SB}$, et al. The role of vitamin $\mathrm{D}$ in cancer prevention. Am J Public Health. 2006;96(2):252-61.

4. Munger KL, Levin LI, Hollis BW, Howard NS, Ascherio A. Serum 25-hydroxyvitamin D levels and risk of multiple sclerosis. JAMA. 2006;296(23):2832-8.

5. Mathieu C, Badenhoop K. Vitamin D and type 1 diabetes: state of the art. Trends Endocrinol Metab. 2005;16(6):261-6.

6. Forouhi NG, Luan J, Cooper A, Boucher BJ, Wareham NJ. Baseline serum 25-hydroxyvitamin $D$ is predictive of future glycemic status and insulin resistance: the Medical Research Council Ely Prospective Study 1990-2000. Diabetes. 2008;57(10):2619-25.

7. Wang TJ, Pencina MJ, Booth SL, Jacques PF, Ingelsson E, Lanier $\mathrm{K}$, et al. Vitamin $\mathrm{D}$ deficiency and risk of cardiovascular disease. Circulation. 2008;117(4):503-11.

8. DeLuca HF. Overview of general physiologic features and functions of vitamin D. Am J Clin Nutr. 2004;80(6):1689S-96S.

9. Bikle D. Nonclassic actions of vitamin D. J Clin Endocrinol Metab. 2009;94(1):26-34.

10. Hyppönen $E$, Läärä $E$, Reunanen $A$, Järvelin MR, Virtanen SM. Intake of vitamin $D$ and risk of type 1 diabetes: a birth-cohort study. Lancet. 2001;358(9292):1500-3.

11. Ortlepp JR, Metrikat J, Albrecht M, Von Korff A, Hanrath P, Hoffmann $R$. The vitamin $D$ receptor gene variant and physical activity predicts fasting glucose levels in health young men. Diabet Med. 2003;20(5):451-4.

12. Holick MF. Vitamin D deficiency. N Engl J Med. 2007;357(3):266-81.

13. Bischoff-Ferrari HA, Willett WC, Wong JB, Giovannucci E, Dietrich T, Dawson-Hughes B. Fracture prevention with vitamin D supplementation: a meta-analysis of randomized controlled trials. JAMA. 2005;293(18):2257-64.

14. Holick MF, Binkley NC, Bischoff-Ferrari HA, Gordon CM, Hanley DA, Heaney RP, et al. Evaluation, treatment, and prevention of vitamin D deficiency: an Endocrine Society Clinical Practice Guideline. J Clin Endocrinol Metab. 2011;96(7):1911-30.

15. IOM (Institute of Medicine). Dietary reference intakes for calcium and vitamin D. Washington, DC: The National Academies Press; 2011. p. 260-2.

16. Bandeira F, Bandeira C, Freese E. Occult vitamin D deficiency and its relationship with bone mineral density among postmenopausal women in Recife, Brazil. J Bone Miner Res. 2003;18(Supl 2):S407- 9.
17. Isaia G, Giorgino $R$, Adami S. High prevalence of hypovitaminosis $D$ in female type 2 diabetic population. Diabetes Care. $2001 ; 24(8): 1496$.

18. Suzuki A, Kotare M, Ono Y, Kato T, Oda N, Hayakawa N, et al. Hypovitaminosis $D$ in type 2 diabetes mellitus: association with microvascular complications and type of treatment. Endocr J. 2006;53(4):503-10.

19. Tahrani AA, Ball A, Shepherd L, Rahim A, Jones AF, Bates A. The prevalence of vitamin $D$ abnormalities in South Asians with type 2 diabetes mellitus in the UK. Int J Clin Pract. 2010;64(3):351-5.

20. Bland R, Markovic D, Hills CE, Hughes SV, Chan SL, Squires PE, et al. Expression of 25-hydroxyvitamin D3-1alpha-hydroxylase in pancreatic islets. J Steroid Biochem Mol Biol. 2004;89-90(15):121-5.

21. Norman AW, Frankel JB, Heldt AM, Grodsky GM. Vitamin D deficiency inhibits pancreatic secretion of insulin. Science. 1980;209(4):823-5.

22. Chiu KC, Chu A, Go VL, Saad MF. Hypovitaminosis D is associated with insulin resistance and beta cell dysfunction. Am J Clin Nutr. 2004;79(5):820-5.

23. Cade C, Norman AW. Vitamin D3 improves impaired glucose tolerance and insulin secretion in the vitamin D-deficient rat in vivo. Endocrinology. 1986;119(1):84-90.

24. Tanaka $Y$, Seino $Y$, Ishida M, Yamaoka K, Yabuuchi $H$, Ishida $H$, et al. Effect of vitamin D3 on the pancreatic secretion of insulin and somatostatin. Acta Endocrinol (Copenh). 1984;105(4):528-33.

25. Maestro B, Dávila N, Carranza MC, Calle C. Identification of a vitamin $D$ response element in the human insulin receptor gene promoter. J Steroid Biochem Mol Biol. 2003;84(2-3):223-30.

26. Sergeev IN, Rhoten WB. 1,25-dihydroxivitamin D3 evokes oscillations of intracellular calcium in a pancreatic beta-cell line. Endocrinology. 1995;136(7):2852-61.

27. Sowers JR. Insulin resistance and hypertension. Am J Physiol Heart Circ Physiol. 2004;286(5):H1597-602.

28. Chiu KC, Chuang LM, Yoon C. The vitamin D receptor polymorfisms in the translation initiation codon is a risk factor for insulin resistance in glucose tolerant Caucasians. BMC Med Genet. 2001;2:2.

29. Gulseth HL, Gjelstad IM, Tierney AC, Lovegrove JA, Defoort $C$, Blaak EE, et al. Serum vitamin D concentration does not predict insulin action or secretion in European subjects with the metabolic syndrome. Diabetes Care. 2010;33(4):923-5.

30. Kayaniyil S, Retnakaran R, Harris S, Vieth R, Knight JA, Gerstein $\mathrm{HC}$, et al. Prospective associations of vitamin $D$ with $\beta$-cell function and glycemia: the PROspective Metabolism and ISlet cell Evaluation (PROMISE) cohort study. Diabetes. 2011;60(11):2947-53.

31. Kayaniyil S, Vieth R, Retnakaran R, Knight JA, QiY, Gerstein HC, et al. Association of vitamin $\mathrm{D}$ with insulin resistance and beta-cell dysfuntion in subjects at risk for type 2 diabetes. Diabetes Care. 2010;33(6):1379-81.

32. Stephensen CB, Marquis GS, Kruzich LA, Douglas SD, Aldrovandi $\mathrm{GM}$, Wilson CW. Vitamin D status in adolescents and young adults with HIV infection. Am J Clin Nutr. 2006;83(5):1135-41.

33. Conrado T, Miranda-Filho DB, Ximenes RA, Albuquerque MF, Lacerda HR, Ramos RC, et al. Vitamin D deficiency in HIV-infected women on antiretroviral therapy living in the tropics. J Int Assc Phys AIDS Care. 2011;10(4):239-45.

34. Boucher BJ, Mannan N, Noonan K, Hales C, Evans JW. Glucose intolerance and impairment of insulin secretion in relation to vitamin $\mathrm{D}$ deficiency in East London Asians. Diabetologia. 1995;38(10):1239-45.

35. Pittas AG, Dawson-Hughes B, Li T, Van Dam RM, Willett WC, Manson JE, et al. Vitamin D and calcium intake in relation to type 2 diabetes in women. Diabetes Care. 2006;29(3):650-6. 
36. Scragg R, Sowers MF, Bell C. Serum 25-hydroxivitamin D, diabetes, and ethnicity in the Third National Health and Nutrition Examination Survey. Diabetes Care. 2004;27(12):2813-8.

37. Ashraf A, Alvarez J, Saenz K, Gower B, McCormick K, Franklin F. Threshold for effects of vitamin D deficiency on glucose metabolism in obese female African-American adolescents. J Clin Endocrinol Metab. 2009,94(9):3200-6.

38. Reis JP, von Mühlen ED, Miller ER, Michos ED, Appel LJ. Vitamin $D$ status and cardiometabolic risk factors in the United States adolescent population. Pediatrics. 2009;124(3):e371-9.

39. Pittas AG, Lau J, Hu FB, Dawson-Hughes B. The role of vitamin D and calcium in type 2 diabetes. A systematic review and metaanalysis. J Clin Endocrinol Metab. 2007;92(6):2017-29.

40. de Boer IH,Tinker LF, Connely S, Curb J, Howard BV, Kestenbaum $B$, et al. Calcium plus vitamin $D$ supplementation and the risk of incident diabetes in the women's health initiative. Diabetes Care. 2008;31(4):701-7.

41. Mitri J, Muraru MD, Pittas AG. Vitamin D and type 2 diabetes: a systematic review. Eur J Clin Nutr. 2011;65(9):1005-15.

42. Mitri J, Dawson-Hughes B, Hu FB, Pittas AG. Effects of vitamin $D$ and calcium supplementation on pancreatic $\beta$ cell function, insulin sensitivity, and glycemia in adults at high risk of diabetes: the Calcium and Vitamin D for Diabetes Mellitus (CaDDM) randomized controlled trial. Am J Clin Nutr. 2011;94(2):486-94.

43. Zittermann A, Schleithoff SS, Koerfer R. Putting cardiovascular disease and vitamin $\mathrm{D}$ insufficiency into perspective. $\mathrm{Br} \mathrm{J}$ Nutr. 2005;94(4):483-92.

44. Wang L, Manson JE, SongY, Sesso HD. Systematic review: vitamin $\mathrm{D}$ and calcium supplementation in prevention of cardiovascular events. Ann Inter Med. 2010;152(5):315-23.

45. Somjen D, Weisman $Y$, Kohen F, Gayer B, Limor R, Sharon O, et al. 25-hydroxyvitamin D3-1alpha-hydroxylase is expressed in human vascular smooth muscle cells and is upregulated by parathyroid hormone and estrogenic compounds. Circulation. 2005;111(13):1666-71.

46. LiYC, Kong J,Wei M, Chen ZF, Liu SQ, Cao LP. 1,25-Dihydroxyvitamin $D(3)$ is a negative endocrine regulator of the renin-angiotensin system. J Clin Invest. 2002;110(2):229-38.

47. Martins D, Wolf M, Pan D, Zadshir A, Tareen N, Thadhani R, et al. Prevalence of cardiovascular risk factors and the serum levels of 25-hydroxyvitamin D in the United States: data from the Third National Health and Nutrition Examination Survey. Arch Intern Med. 2007;167(11):1159-65.

48. Pilz S, März W, Wellnitz B, Seelhorst U, Fahrleitner-Pammer A, Dimai HP, et al. Association of vitamin D deficiency with heart failure and sudden cardiac death in a large cross-sectional study of patients referred for coronary angiography. J Clin Endocrinol Metab. 2008;93(10):3927-35.

49. Elamin MB, Abu ENO, Elamin KB, Fatourechi MM, Alkatb AA, Almandoz JP, et al. Vitamin D and cardiovascular outcomes: a systematic review and meta-analysis. J Clin Endocrinol Metab. 2011;96(7):1931-42.

50. Targher G, Bertolini L, Padovani R, Zenari L, Scala L, Cigolini M, et al. Serum 25-hydroxyvitamin D3 concentrations and carotid artery intima-media thickness among type 2 diabetic patients. Clin Endocrinol (Oxf). 2006;65(5):593-7.

51. Provvedini DM, Manolagas SC. 1 Alpha,25-dihydroxyvitamin D3 receptor distribution and effects in subpopulations of normal humanT Iymphocytes. J Clin Endocrinol Metab. 1989;68(4):744-9.

52. Gregori S, Giarratana N, Smiroldo S, Uskokovic M, Adorini L. A 1alpha,25-dihydroxyvitamin $\mathrm{D}(3)$ analog enhances regulatory T-cells and arrests autoimmune diabetes in NOD mice. Diabetes. 2002;51(5):1367-74.

53. Riachy R, Vandewalle B, Moerman E, Belaich S, Lukowiak B, Gmyr $\mathrm{V}$, et al. 1,25-Dihydroxyvitamin D3 protects human pancreatic islets against cytokine-induced apoptosis via down-regulation of the Fas receptor. Apoptosis. 2006;11(2):151-9.

54. Willhein M, Thien R, Schrattbauer K, Bajna E, Holub M, Gruber R, et al. Regulatory effects of 1alpha,25-dihydroxyvitamin D3 on the cytokine production of human peripheral blood lymphocytes. J Clin Endocrinol Metab. 1999;84(10):3739-44.

55. Hyppönen E. Vitamin D and increasing incidence of type 1 diabetesevidence for an association? Diab Obes Metab. 2010;12(9):737-43.

56. Ramos-Lopez E, Jansen T, Ivaskevicius V, Kahles H, Klepzig C, Oldenburg J, et al. Protection from type 1 diabetes by vitamin D receptor haplotypes. Ann NY Acad Sci. 2006;1079:327-34.

57. Bailey R, Cooper JD, Zeitels L, Smyth DJ, Yang JH, Walker NM, et al. Association of the vitamin D metabolism gene CYP27B1 with type 1 diabetes. Diabetes. 2007;56(10):2616-21.

58. Walter M, Kaupper T, Adler K, Foresch J, Bonifacio E, Ziegler AG. No effect of the 1alpha,25-dihydroxyvitamin D3 on beta-cell residual function and insulin requirement in adults with newonset type 1 diabetes. Diabetes Care. 2010;33(7):1443-8.

59. Bizzarri C, Pitocco D, Napoli N, Stasio E, Maggi D, Manfrini S, et al. IMDIAB Group. No protective effect of calcitriol on betacell function in recent-onset type 1 diabetes: the IMDIAB XIII trial. Diabetes Care. 2010;33(9):1962-3.

60. Gabbay MA, Sato MN, Finazzo C, Duarte AJ, Dib SA. Effect of cholecalciferol as adjunctive therapy with insulin on protective immunologic profile and decline of residual $\beta$-cell function in new-onset type 1 diabetes mellitus. Arch Pediatr Adolesc Med. 2012;166(7):601-7. 